The Geneva Papers on Risk and Insurance, 17 (No. 65, October 1992), 446-467

\title{
The Comparative Efficacy of Tort Law and Regulation for Environmental Protection 1
}

\author{
by Donald N. Dewees*
}

\section{Introduction}

During the last two decades those interested in environmental improvement have turned to regulatory agencies, particularly in the U.S. to the federal Environmental Protection Agency, as the principal instrument for achieving their ends. Certainly these regulatory institutions play an important role in deterring the considerable damage done by environmental pollution. But long before the creation of the U.S. Environmental Protection Agency (EPA) or the many state EPA's, and before the principal pollution control statutes were enacted, the common law of tort provided a seemingly powerful set of rights to pollution victims that might also deter damaging pollution discharge. A person was entitled to the enjoyment of his property free from unreasonable interference from pollution, and riparian property owners were entitled to the flow of water undiminished in quantity and quality. This paper considers whether the focus on government regulation by the public and by economists has ignored an important and effective private tool for improving environmental management, and what role tort might play in the future. The paper will review what we know about the performance of the tort system and the regulatory system with regard to their ability to control pollution discharge and to limit the harm that such discharge causes. The review concentrates on the United States, with some consideration of Canada, and on the effectiveness of policy rather than on its economic efficiency.

The "environmental" problems considered here include injuries to persons, property or the environment caused by the discharge of air and water pollution and by the discharge and disposal of solid and liquid wastes. I exclude lawsuits arising out of workplace exposures

* University of Toronto.

1 This paper draws on a much larger study entitled "The Efficacy of the Tort System and Its Alternatives: A Review of the Empirical Evidence" undertaken for the American Law Institute. Portions have appeared in a paper presented to an AERE workshop on innovations in environmental law (Dewees 1992b). I wish to thank participants in that workshop, in the 1991 conference of the European Association for Law and Economics, in the economics workshops at York University, Michael Trebilcock, Michael Faure and Janet Landa, for comments on earlier versions of the paper. Funding has been provided by the Social Sciencies and Humanities Research Council of Canada and by the Ontario Ministry of the Environment. 
and product-liability actions that do not include environmental (outdoor) exposure. Thus while asbestos is often regarded as an environmental problem, most of the litigation in the United States has arisen from workplace exposures (Brodeur 1985) and is clearly a matter of occupational not environmental health, with the lawsuits taking the form of product liability claims. The Agent Orange case (Schuck 1986) is also a product-liability case.

The classic environmental tort actions are based on private nuisance, trespass, public nuisance, negligence, riparian rights and on Rylands $v$. Fletcher. This paper will focus on the first four causes of action. It will not consider civil actions based on liability created by statutes such as the Comprehensive Environmental Response Compensation and Liability Act, CERCLA. ${ }^{2}$ Such actions represent a rapidly growing area of environmental civil litigation, but one that is distinct from common law tort. Regulatory statutes include the major U.S. federal air and water pollution legislation and regulations under those statutes. Canadian law is considered briefly.

\section{The evaluative framework}

What criteria should be used in evaluating the efficacy of the tort system and the regulatory system? Law and economics scholars, drawing on concepts of economic efficiency, stress the deterrent objectives of the tort system and evaluate legal doctrine in terms of whether appropriate incentives are created to induce the parties to minimize the sum of accident and avoidance costs by taking cost-justified precautions. (See Shavell 1987; Polinsky 1989; Cooter and Ulen 1988, Chapter 8; Landes and Posner 1987.) Other scholars argue that the tort system should be evaluated against its capacity to spread risk and to compensate accident victims (Sugarman 1985; Abel 1987), or against its ability to impose on a wrongdoer the duty to fully compensate the victim (Weinrib 1989). The regulatory system may also be evaluated with respect to its ability to control pollution discharge and to compensate victims. This paper will focus on the deterrence objective for both systems.

Shavell (1984) presents four factors to explain why we use tort law to control some activities and government regulation to control others: differences in knowledge about the risky activity as between private parties and a regulatory authority; ability of private injurers to pay for the harm that they cause; likelihood that injurers will actually be sued for the harm done; and administrative costs. He argues that pollution, among other activities, is usually best controlled by government regulation. The information required to reach optimal pollution control decisions if often quite similar for many situations involving a given pollutant, so a single government agency is more likely to be well-informed about costs and benefits than are individual plaintiffs, and it is more economical for the agency to gather the requisite information than for the parties to assemble and present it to the courts many times in successive suits. There are a number of environmental pollution problems in which the resources of the polluter would be inadequate to compensate for the harm done, especially when toxic substances are involved, so liability could not impose an efficient deterrent. Most important, in many cases, victims are unlikely to sue, because the pollutants are widely dispersed so that each victim suffers little harm; because injuries often manifest themselves years after the discharge took place; and because if causation can be proven at all it is on a statistical and not an individual basis. Shavell's theoretical

\footnotetext{
${ }^{3}$ Pub.L.No. 96-510, 94 Stat. 2767, 42 U.S.C. $\S \S 9601-9675$ (1982 \& Supp IV. 1986).
} 
framework appears to support primary reliance on government regulation rather than on tort for controlling environmental pollution.

In theory, the performance of the two systems could be evaluated by developing an index of pollution and performing a statistical analysis of the effect of the tort system and the regulatory system on that index. However the data required to extract convincing results from such a study are daunting. For that reason, this paper places primary emphasis on an analysis of the inputs to the tort litigation process and the regulatory process. The analysis of inputs determines the theoretical assumptions that are required for the tort system, or the regulatory system, to provide optimal deterrence, and examines whether those assumptions are satisfied by legal doctrines, legislation, regulation, and empirical facts. This is followed by an analysis of outputs which examines actual performance itself, attempting to identify the changes in behaviour that the tort system and the regulatory system have induced, and then examining whether these changes are consistent with optimal deterrence.

\section{Tort law}

\subsection{Input evaluation}

\subsubsection{Market failure and optimal remedies}

Coase (1960) noted that if the law was clear, the number of parties small, and transactions costs low, then polluters and pollutees could negotiate to an efficient level of pollution control. Strikingly, the outcome would be optimal regardless of whether the law imposed liability for pollution damage or not. In these situations, the parties should be able to resolve the problem efficiently. Unfortunately, few environmental problems arise between a single polluter and a single pollutee. The overwhelming preponderance of pollution problems arise with multiple victims, often with multiple sources, and often with great uncertainty relating to discharge, dispersion and harm. Here the negotiations postulated by Coase will not take place, as he recognizes in his high transactions costs case. Thus we require careful examination of tort doctrine to determine whether an efficient solution will be reached.

Consider a single polluter and a number of victims where the efficient outcome may involve joint precautions by both polluters and pollutees. The economic literature on the efficient solution to this problem is clear: the polluter must pay for the actual social damage resulting from his pollution discharge, and victims should not be compensated, to avoid excess activity and entry (Baumol and Oates 1988, Ch. 4). The general prescription for this problem is a Pigovian tax on pollution discharge. Because the victims are not in a market relationship with the polluter, payment by the polluter will arise only if the tort system compels it, or if a government agency imposes liability. The first half of the prescription, that the polluter pay for all harm caused, should be obvious as a means of inducing optimal deterrence. The second half, that victims should not be compensated, is less obvious. The rationale is that if victims are fully compensated for all harm that they suffer, then there is theoretically nothing to deter sensitive victims from moving close to a source of pollution, because they will be made whole for any losses that they suffer. Neither is there an incentive for victims to mitigate their damages by engaging in less rather than more sensitive activities. A complete absence of compensation for victims will generate incentives for optimal levels of precaution by those victims. 
The law and economics literature on efficiency in nuisance law is roughly consistent with this economics literature. It is recognized that efficiency requires that the parties on both sides face the social costs of their actions; that the polluter must at the margin pay for the incremental harm that he causes, and that victims must not be compensated for excess harm that they could have avoided at a lesser cost. Landes and Posner conclude that courts in the United States approximate the results required by economic efficiency. In nuisance law, for instance, the requirement that there be substantial harm and unreasonable use before an injunction will be awarded recognizes the two-sided nature of pollution problems and that, generally, polluters should not be required to stop polluting unless the damage caused exceeds the cost of abatement (Posner 1986, p. 56; Landes and Posner 1987, p. 44).

\subsubsection{Are common law liability rules efficient?}

The doctrine of private nuisance protects interests in land, and the doctrine of public nuisance protects other interests. In Canada, common law private nuisance actions protect an owner or tenant from unreasonable interference with the use and enjoyment of land. Pollution that causes physical damage including injury to health is actionable but it is unsettled whether injury to health alone will support a claim in nuisance. If the interference causes only a reduction in enjoyment, not physical damage, then the test applied is whether an ordinary person would be offended; the extraordinarily sensitive landowner or his property is not protected from invasion. This is equivalent to a "reasonable victim" rule. Defenses may also arise if the neighbourhood is one in which the pollution complained of is to be expected because of the industrial character of the neighbourhood. Courts may award injunctive relief or damages but an injunction will be awarded only if the injury is substantial and continuing (Linden 1988, pp. 500-519).

In the United States, an action in private nuisance can be supported when there is damage that is "substantial and unreasonable". The defendant's action must be intentional in the sense that a condition is created or continued with knowledge that the interference is or is likely to harm the plaintiff's interests. Substantial and unreasonable harm can include physical harm to land or property, and physical discomfort or annoyance. Injunctive relief is rare, requiring unreasonable conduct on the part of the defendant as well as substantial and unreasonable harm to the plaintiff's interests. Unreasonable conduct is determined by "balancing the equities" which allows the court to consider, among other things, the social utility of the polluting activity. The onus is on the plaintiff to show that the gravity of the harm outweighs the utility of the conduct. Theoretically, only damages are awarded when there is no determination of unreasonable conduct. It is unclear whether or not courts also consider the nature of the defendant's conduct when determining whether the interference with the plaintiff is unreasonable. An injunction will not be awarded simply on the basis of the inadequacy of damages (Keeton et. al. 1984, pp. 624-634).

There is a defence for "coming to the nuisance" which often bars actions by plaintiffs arriving after the discharge was established. While this will discourage excessive entry by victims, it fails to impose on the polluter the cost of the harm he causes. As in Canada there are defenses based on the reasonableness of the victim and on the character of the neighbourhood. Again those suffering modest invasion are likely to be left with no recourse in private nuisance. 
In both countries then the liability rules for private nuisance seem to exclude recovery for harm that is insubstantial or reasonable, or which results from the plaintiff's special sensitivity, yet such cases may represent a substantial proportion of pollution discharge. If the nuisance is "unintentional" the conduct required to sustain an action must be negligent, reckless, or ultrahazardous with respect to the plaintiff's interests.

Trespass protects interests in real property from tangible invasion. Originally intended to protect against others coming onto or using one's land, the doctrine has been extended to include the settling of dusts and vapors on one's property, and even small invasions are actionable, including smells and vapors (Grad 1985, pp. 2-36 to 2-39, 2-47 to 2-52). Unlike private nuisance, there is no defense associated with the reasonable conduct of the defendant, or with the plaintiff's having arrived after the defendant. Thus trespass may be available in some cases when private nuisance is not.

The law of public nuisance may be used to address violations of a general interest in environmental quality through an action brought by the government rather than by a private individual (Keeton et al. 1984, $\S 90$ pp. 643-648). Actions may be brought by individuals if they can demonstrate that their losses differ in kind, not quality, from those of the rest of the community. Public nuisance is broader than private nuisance and can be applied to interference with public health, public comfort, and public convenience. The harm must be widespread and substantial. It would appear that major discharges of toxic substances could probably qualify as a public nuisance (Environmental Law Institute 1980, p. 480). However private individuals can rarely sue, and governments rarely do, so this doctrine is of little effect. Public nuisance was similarly ineffective in Great Britain in the 19th century, for the same reasons (Brenner 1974).

Negligence actions may be applied regardless of proprietary interest. While relatively little environmental litigation has relied upon negligence doctrine, some commentators fear that courts could begin to expand from negligence to strict liability and beyond in the environmental field as they have in product liability (Abraham 1988, p. 974). In the field of product liability, the courts have imposed liability for past conduct that was not wrongful when the defendant acted, and in fact could not have been discovered to have been harmful at that time, a form of retroactive strict liability. ${ }^{3}$ The Superfund legislation imposes retroactive strict liability with joint and several liability for the tortfeasers, and some worry that the courts may begin to apply similar principles to common law environmental tort claims, a development that could vastly expand the scope of liability for environmental pollution (Abraham 1988, p. 925). While these developments have not occurred, the fear that they might has affected current perceptions of the crisis in environmental litigation.

In summary, the Canadian rules appear to impose on the polluter the full cost of substantial pollution discharges that affect property owners which are found unreasonable in the circumstances and of some discharges that are not unreasonable. They may over-deter discharges causing physical harm, since the victim is entitled to an injunction and, where there are large numbers of victims, Coasian bargaining cannot take place. Widely dispersed pollution discharge will be under-deterred because small amounts of harm suffered by a large number of victims will not support an action in private nuisance. The U.S. rules

\footnotetext{
${ }^{3}$ Beshada v. Johns-Manville Products Corp., 90 N. J. 191, 447 A.2d 539 (1982).
} 
provide less complete deterrence, since the requirement to balance the reasonableness of the conduct of the plaintiff and that of the defendant will fail to impose costs on polluters in a large number of cases. While this would be efficient if the test for "reasonable" were a cost-benefit test, it is unlikely that the courts can perform this calculation accurately, given the difficulty of determining abatement costs and damage costs for large numbers of victims. The defense that the pollution was consistent with the neighborhood also precludes many actions. The evidence that victims are often undercompensated also supports the conclusion that benefits will be understated, leading to underdeterrence. Furthermore, the defense of coming to the nuisance relieves many U.S. polluters of liability. Most important, however, is the fact that injuries not associated with private property, including long-term damage to ecosystems that are a source of considerable concern among environmentalists, are generally not well protected by the doctrines discussed here. The assertion by Landes and Posner that these doctrines are efficient seems overstated.

\subsubsection{Claims initiation: do lawsuite actually impose full costs?}

Significant barriers to claims initiation arise in common law environmental cases from problems in proving causation, statutes of limitation, and costs. The result of these barriers is that legal action is rarely taken and when taken is often unsuccessful, so that polluters are not faced with the full social costs of their activities.

\section{a. Causation}

A major barrier to success in claims for air and water pollution problems is the difficulty of proving causation. A successful plaintiff must prove that he has suffered actual harm, that the harm arose from a specific pollutant, that the pollutant is of a type discharged by the defendant, and that this pollutant arose from the defendant and not from some other polluter (Developments 1986, pp. 1617-1630). In the case of an isolated factory discharging a concentrated waste that causes a unique form of harm, these burdens may all be surmounted. It is more difficult, but still possible, to trace pollution discharged into a stream back to the pollution source, and some river pollution cases have been successful (Grad 1985, § 3.02). Still, if there are multiple polluters, it may be very expensive to determine who is responsible for what portion of the contamination in the river and then to ascertain the effect of that contamination on the aquatic ecosystem. The difficulty of proving one or more of the four elements of causation is a crippling barrier to traditional tort lawsuits for the vast majority of pollution problems experienced in North America. The situations where causation is not an important barrier are likely to involve a large isolated pollution source causing a characteristic form of damage, and these are precisely the sources most likely to have attracted the attention and control of regulatory authorities. Even in such circumstances, causation may raise problems (Dewees 1992a).

Some developments have served to lessen the burden of causation in situations typical of environmental injury. Joint and several liability has been applied when a single defendant cannot be identified, and when the harm is "indivisible" (Brennan 1986, p. 112). While this approach is obviously beneficial for plaintiffs, it may confront some defendants with far more than the full social costs of their activities leaving others cost-free. Other emerging types of joint liability include market share liability and enterprise liability (Developments 1986, pp. 1624-1630).

Lack of knowledge about exposure to a hazardous substance is a barrier to suit that has been considerably reduced since the mid-1980's. Under OSHA regulations, manu- 
facturers of hazardous materials must inform users of the presence of the material and its characteristics, ${ }^{4}$ which should inform workers about hazards in the workplace. Title III of the Superfund Amendment and Reauthorization Act ${ }^{5}$ provides for community right-toknow, which requires sources to notify local, state, and federal public officials of the presence and release of any of a number of potentially hazardous chemicals. Information about such releases or even the presence of the chemicals in the community will facilitate the proof of causation for some victims, probably increasing litigation.

Traditionally, liability could be imposed only when it could be shown that it is more likely than not that this defendant caused this plaintiff's harm. A modern version of this rule would find causation when the attributable risk or the probability of causation exceeds fifty percent. Yet only a horrific exposure to the most potent carcinogens would raise to 50 percent the probability that a common cancer, such as lung cancer, was caused by that chemical, so only rarely could cancer victims succeed in recovering from dischargers of known carcinogens. Even if a given pollution discharge were proven to have raised the lung cancer rate in a population by one-third, no lung cancer victim could recover. And in the rare cases where exposure to a pollutant gave rise to a 50 percent cancer risk, if there were multiple sources, no individual source may be found liable.

In the product liability area this problem has been addressed with market share liability, but this concept is not widespread for environmental injury. While some courts have moved to accept statistical evidence of causation (Developments 1986, p. 1619), Brennan (1988) has advocated the use of science panels to assist courts in fact finding, and Shavell has recommended liability proportional to the probability of causation (proportionate liability), these proposals are still not widely accepted.

As courts have struggled to find relief for plaintiffs with serious health problems, Huber (1988, p. 153) has suggested that they have found causation where non existed at all. Previous problems of inadequate deterrence may be joined by problems of deterrence without proven causation, not obviously a step toward efficient deterrence.

Unfortunately, reliable epidemiological data are available for very few toxic substances, and since epidemiological studies require large numbers of victims to be reliable, the number of substances for which the dose-response function is well-understood may grow very slowly. In this circumstance, even the likely underdeterrence identified above does not incline me to advocate substantial easing of the burden of proving causation. While proportionate liability and science panels are theoretically attractive, inviting U.S. courts to find some liability for diseases suffered by large numbers of injured people runs the risk of opening yet another giant legal lottery in which the uncertainties of fact-finding leave little likelihood that justice, or efficient deterrence, will be done. The high cost of the legal system ensures that considerable resources would be consumed. While the present system quite likely achieves substantial underdeterrence, more tort is not clearly a solution.

\footnotetext{
${ }^{4}$ Hazard Communication Standard, 29 C.F.R. $§ 1910.1200$ (1987).

542 U.S.C. $\$ 11001-11050$ (Supp. IV 1986).
} 


\section{b. Statutes of limitation}

The traditional rule that lawsuits may not be filed more than two or three years from the time of injury or from the time of the tortious act is a barrier to plaintiffs suffering from latent illness or who are not immediately aware of their injury and also to owners of property contaminated by toxic materials first discharged or deposited long ago (Developments 1986, p. 1605). The "discovery" rule, which dictates that limitation periods run from the time when the injury is or ought reasonably to have been discovered, preserves the right of victims of latent injuries to take legal action and thereby better serves the deterrence objective. The U.S. Supreme Court endorsed this rule for latent personal injuries in 1949, and by 198232 states had adopted it (Developments 1986, p. 1606). Still, the risk of a lawsuit decades after the pollution is discharged may not act as an effective deterrent to all but the most foresighted firms (Dewees 1986).

\section{c. Costs}

Most air and water pollution discharges impose small costs on large numbers of people. It is rarely worthwhile for individuals to litigate these matters because individual damages will fall significantly short of the legal costs required for maintaining an action. This is particularly true in Canada where costs follow the event so that any substantial risk of losing a lawsuit means a substantial risk of being responsible for one's own legal fees and for the legal fees of the other side. It is especially true in Ontario where contingent fees have been prohibited.

One solution to this problem of course is the aggregation of claims, most commonly achieved in the United States through the class action lawsuit, which was facilitated by amendments to the Federal Rules of Civil Procedure in 1966.6 The solution is not perfect however since environmental exposure cases will not always lend themselves to class actions, for example when injuries to different members of the class arise at different times and are of widely varying severity. Furthermore, there are substantial costs associated with identifying and certifying the class, and then with distributing the proceeds if the action is successful (Schuck 1986).

Finally, costs represent a significant drain on compensation eventually paid. A 1985 study estimated that, considering all tort cases, plaintiffs retain $46 \%$ of total litigation expenditures as compensation (Kakalik and Pace 1986). A 1983 Rand study of asbestos litigation found that of the $\$ 661$ million in total expenditures by defendants and their insurers on asbestos cases that had been closed by 1982 , the plaintiffs received only $37 \%$ of that total, while $63 \%$ was consumed in litigation (Kakalik et al. 1983, p. vi.). Environmental litigation may be even more expensive than asbestos litigation because of the problems discussed above and because even less is usually known about the harmfull effects of the substances in question than about asbestos.

\subsubsection{Claims resolution}

Do courts actually award appropriate damages in environmental cases? The Environmental Law Institute (1980) study of toxic pollution concluded that compensation in environmental exposure cases is significantly inadequate. The obstacles cited include legal remoteness of damages, valuation of damages, and the exclusion from compensation of

\footnotetext{
${ }^{6}$ Fed. Rules Civ. Proc. Rule 23, 28 U.S.C.
} 
latent medical effects and barriers to claims initiation. Since that study was conducted compensation awards have increased significantly (Huber 1988, p. 136), but it is not clear that the gap has been closed. Furthermore, with respect to suits for the contamination of property by toxic or hazardous waste, where the cost of restoration may be enormous, the responsible party may often not have assets sufficient to satisfy a judgment obtained by a successful plaintiff.

\subsection{Output evaluation}

The deterrent effects of tort liability may appear in various forms: increased pollution control expenditures, reduced pollution discharge, reduced environmental damage, or the introduction of environmental factors into the decision-making process of polluting organizations. But environmental protection is a response not only to tort liability but also to an amalgam of laws and regulations promulgated by virtually all levels of government in the wake of growing scientific awareness and public concern for environmental issues, and to a desire to maintain a favorable public image. Unfortunately, the aggregate data on pollution abatement usually do not provide a basis for identifying the cause of such abatement as has occurred, so the output evidence is of limited relevance in assessing the contribution of tort law. Several case studies, reported elsewhere, provide some supplementary evidence which will be summarized below.

The review of inputs leads me to expect little deterrent effect from tort prior to 1980 . Since 1980, the expansion of liability for hazardous waste sites should have led to increased care in the disposal of hazardous wastes and some reduction in the volume and toxicity of those wastes. As scientific capabilities for tracing pollutants to their source have improved, and as we have developed information about the harm caused by some pollutants, we might expect to find some reduced pollution emissions arising from an increased risk of tort lawsuits, where the harm is predictably large, and where the pollution may be traced easily, as in the case of soil or ground water contamination. The question, then, is whether there is evidence that litigation has played more than the minimal role suggested by the input analysis above.

\subsubsection{Pollution control expenditures}

Between 1972 and 1988, real business spending on pollution abatement and control increased by about 70 percent, from about $\$ 28$ billion to $\$ 48$ billion in 1982 dollars (Bratton and Rutledge 1990, p. 33). Of this spending, the capital investment portion was relatively constant, while operating costs nearly doubled; both experienced a small decline in the early years of the Reagan administration. This increase is consistent with increasing regulatory demands during this period, and does not reveal a burst of spending in the 1980 's that could be attributed to tort litigation. Indeed, if one looks at the pollution abatement share of total business expenditures on new plant and equipment, that share rose from 3.5 percent in 1972 to more than $4 \%$ in 1975, then fell steadily to about 2 percent in 1988 (Rutledge and Stergioulas 1988, p. 27). This pattern is consistent with a boost in spending in response to the legislation of the early 1970 's, followed by a decline as abatement investment outpaced increases in the stringency of regulation. The only evidence of a response to massive environmental liability in the 1980's is the increasing of new plant and equipment expenditure for pollution control that is dedicated to waste disposal. This increase is attributable to CERCLA regulations, and perhaps to fears of liability arising 
from CERCLA or from tort law. Personal spending on pollution abatement and control, representing the cost of motor vehicle emission controls, tripled during the same period, a direct response to regulation, not to litigation. Except with respect to waste disposal, these statistics do not reveal a response to what has been described as growing environmental liability; they are consistent with the view that tort law has not caused a significant increase in pollution control since the mid-1970's.

\subsubsection{Pollution emissions}

Data on annual emission rates for the six traditional air pollutants from 1970 to 1988 reveal considerable reductions in the emissions of most pollutants, particularly when the growth in population and economic activity are taken into account (EPA 1990, Table 1). Might these reductions be attributed to the tort liability system? That seems unlikely for several reasons. First, the barriers to tort litigation discussed above are directly applicable to these pollutants which are emitted from many sources and which do not cause specific diseases. It would be virtually impossible for an individual in a major metropolitan area to prove that a single source of these pollutants had caused his injury, or even that his injury arose from air pollution at all. There is no evidence of litigation that could have caused these reductions.

Second, regulation provides a clear explanation for the reductions. Motor vehicle regulations have greatly reduced the emissions of hydrocarbons (VOC's) and carbon monoxide, and reduced by about half the emissions per mile of oxides of nitrogen. The emission control systems resulting from those regulations have required unleaded gasoline for many vehicles, and EPA regulations have further limited the amount of lead in gasoline. These regulations together account for most of the reduction in emissions of lead, nitrogen oxides and carbon monoxide and much of the VOC reduction. Tort litigation has played no part in motor vehicle pollution control. If these emissions data demonstrate success in the fight against air pollution, the credit must go to regulation, not to the tort system.

In the case of water pollution control, it will be argued below that the gains since 1970 have been modest. Again, I have not found evidence of litigation that would explain a significant portion of even this limited abatement.

\subsubsection{Corporate decision-making}

The Rand Corporation studied corporate responses to, and the economic consequences of, expanded civil liability in all areas (Reuter 1988). The study is based on a series of interviews with senior corporate officials from the chemical industry, the pharmaceutical industry, the semi-conductor industry, and small firms. Of all the varieties of liability, the expansion of environmental liability, including that arising from CERCLA, is identified along with product liability and wrongful dismissal liability as having the most significant influence on corporate behaviour. The responses indicate that environmental liability has had its greatest effect with respect to land contamination by toxic wastes, where liability is governed by CERCLA, and do not indicate that there has been a significant effect on traditional air and water pollution discharge.

The Chemical Manufacturers Association has surveyed its members' hazardous waste management practices annually since 1981 . Between 1981 and 1985 the value of chemical shipments in the U.S. rose from $\$ 180.5$ billion to $\$ 214$ billion. At the same time, waste 
generation decreased by $51.8 \%{ }^{7}$ Between 1981 and 1987 the use of landfills for disposal decreased by $64 \%$ and incineration use increased. No reasons are given for these changes but the desire to avoid cleanup liability by minimizing disposal activity may very well have been a factor along with increased costs of disposal resulting from greater care by disposal sites attributable to both more extensive regulation and tort liability.

\subsubsection{Case studies}

A review of eight studies of industries or regions in which significant pollution abatement occurred provides some insight into causes of pollution abatement, but reveal that tort played no role in half of the cases and only a modest role in the others. Descriptions of smoke abatement in industrialized United States cities in the first half of this century emphasize activism and regulation. Little credit is given to the operation of the tort system (Grinder 1980, p. 92; Thackery 1967, p. 139). The remarkable elimination of smoke in Pittsburgh, Pennsylvania in the decade after World War II is primarily attributable to vigorous enforcement of municipal and county regulations; tort law was described as "useless" for dealing with smoke (Wurts 1954, p. 1). While there has been a considerable reduction in emissions from motor vehicles since 1970 , this is entirely attributable to regulation, and not to tort litigation. The reduction in phosphorous and DDT pollution in the Great Lakes during the last 30 years has been driven by regulation, not tort litigation (Colborn et al. 1990). Case studies of abatement of sulphur dioxide emissions from nonferrous smelters in Canada, and of mercury discharge from chlor-alkali plants in Canada and the U.K. conclude that tort liability or the threat of liability may have been a factor, but that regulation was at least as important (Dewees 1990; Ashworth, Papps and Storey 1987). Abatement of particulate and sulphur dioxide emissions from the electric utility industry has been driven primarily by regulation, although there are a few situations where major plants have caused local damage and tort claims have led to abatement or taller smokestacks (Roberts and Bluhm 1981, p. 165). In the chemical industry some abatement has arisen from litigation, but most of this has arisen under statutes such as CERCLA rather than under common law tort. There are few classes of pollution discharge for which it can be demonstrated that tort litigation was the primary factor in achieving substantial reductions.

\section{Government regulation}

The traditional form of government regulation is command and control regulation and standard setting which prohibit specific forms of behavior. While local and state laws have long restricted pollution, the legislation that has the greatest force today was enacted during the 1970's and 1980's, much of it at the federal level in the United States. In the United States, Congress delegates authority to the Environmental Protection Agency (EPA) to set standards within the broad terms set by Congress, and the EPA in turn requires the individual states to establish regulatory programs that will achieve the federally mandated objectives, within minimum standards set by the EPA.

EPA regulations set ambient environmental quality goals and establish regulations designed to achieve those goals. We may measure the effectiveness of this regulatory scheme by examining inputs to the regulatory process, assessing whether the methods and

\footnotetext{
${ }^{7}$ Environmental Science and Technology, 22, September 1988, p. 1003.
} 
resources applied are capable of achieving significant environmental improvement, and whether they are likely to do so. We may also examine the outcomes of that regulatory scheme, looking for indications that the scheme has demonstrably improved the environment.

\subsection{Input analysis}

The ability to regulate wisely is dependent upon the government agency acquiring information regarding the hazards presented by substances being discharged and the costs and benefits of reducing that discharge. Unfortunately, the information available to even a diligent agency is often meagre. Years have been required to develop emission inventories for air and water pollution discharge, and still there are large uncertainties about who discharges what, particularly for smaller pollution sources. Of even greater concern, there is limited scientific information about the environmental and health effects of most substances. The National Research Council of the National Academy of Sciences in 1984 concluded that there were no toxicity data whatsoever for over 80 percent of the chemicals regulated under the Toxic Substances Control Act (Shapiro 1990, p. 220). Human doseresponse data reliable enough to support a reasonable estimate of the dose-response function currently exist for only a few pollutants. In a study of chemicals regulated by occupational health and safety standards, only 3 out of the 12 substances studied yielded sufficient evidence to support a reasonable estimate of the dose-response function (Dewees and Daniels 1988, p. 57). Quantitative data on the environmental impact of most substances is equally rare. Estimating costs and feasibility of pollution control is also difficult, and while it is often possible to derive quantitative estimates for the control of most pollutants, those estimates are subject to considerable uncertainty (Portney 1990, pp. 63-69).

The success of environmental regulation may also be measured by assessing the proportion of all environmental problems that has been subjected to effective regulation. In the United States, the EPA has established ambient air quality criteria for six pollutants, and emission limits have been set to achieve these criteria (Tietenberg 1988, p. 338). In addition to regulating criteria pollutants, the EPA has regulated emissions of hazardous pollutants through section 112 of the Clean Air Act, but progress has been slow. Discharge standards exist for only 5 pollutants: asbestos, beryllium, mercury, vinyl chloride, and benzene (Mendeloff 1988, p. 2), while a study conducted by the EPA itself identified 43 potentially hazardous substances for regulation under section 112 (Crandall and Portney 1984 , p. 48). Federal regulation of water pollution has also proceeded slowly (Freeman 1990 , p. 112) and this regulation has focused on point sources, yet non-point sources account for the majority of the discharge of the traditional water pollutants (Freeman 1990, p. 109). Under the Toxic Substances Control Act of $1976^{8}$ only a few chemicals have been banned or regulated (Shapiro 1990, p. 225).

Once regulations and prohibitions have been adopted, sources must be identified and monitored to determine compliance with the regulations, and sanctions must be imposed upon violators. The EPA has established networks for monitoring ambient air and water quality, but while these provide some information on overall pollution trends they are of limited use for identifying and prosecuting violators. There are far too many air and water

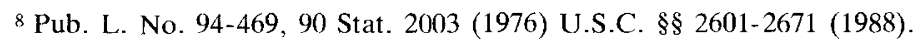


pollution sources for the EPA or even the states to monitor comprehensively, so there has been considerable reliance on self-monitoring of source discharges. The most extensive government monitoring has covered initial compliance, determining whether the facility or equipment meets regulatory standards. Monitoring for continuing compliance is far less complete, despite concern that poor operation of the equipment may greatly increase emissions (Russell 1990). While monitoring and enforcement activities are often said to be inadequate, it is unlikely that budgets for these functions will increase significantly in the near future.

The cost of information necessary to the regulatory process, and the serious resource constraints that afflict all environmental agencies will seriously constrain the pace at which regulations can be imposed and the degree to which they can be enforced. Even an agency with the vast resources of the U.S. EPA will be able to act effectively against only a limited number of pollutants and types of sources in any year. While this means that we will continually discover pollutant emissions for which we will wish to impose more strict regulations, this does not demonstrate that the regulatory process is sub-optimal, since the costs of generating the necessary information are real resource costs and must be considered in evaluating the regulatory program.

\subsection{Output analysis}

The effects of environmental regulation may be measured in any of three ways. First there is the response by polluters, which may be observed in pollution control expenditures and in measured emission reductions. Second, there is the improvement in ambient pollution concentrations arising from the reduced discharge, either absolute improvements, or improvement compared to what would have occurred in the absence of regulation. Third, there is a reduction in the damage caused by pollution, arising from the reduced pollution concentrations, which is of course the ultimate objective of the regulations.

\subsubsection{Polluter response}

Whether regulations have succeeded in reducing emissions depends in part upon the baseline against which reductions are measured. One might expect pollution emissions to rise in proportion to population, to economic activity (e.g. gross national product or GNP), or to fossil fuel consumption. This is important because of the 20 percent increase in the U.S. population, the 66 percent increase in real GNP, the 12 percent increase in fossil fuel consumption and the 53 percent increase in coal consumption between 1970 and 1988 (Dewees and Trebilcock 1991, Table 3).

Data compiled by Bratton and Rutledge (1990, p. 32) reveal pollution control expenditures that rose steadily from 1972 to 1988 , except for public sewer construction, which peaked in the 1970's. The EPA (1990) has estimated air pollution emissions rates for major pollutants from 1940 to the present. These data provide a basis for assessing the impact or regulation on polluter behaviour.

Expenditures for motor vehicle emission control account for more than one-third of all air pollution control expenditures in the 1980's. These expenditures, which tripled between the early 1970's and the late 1980's (Bratton and Rutledge 1990, p. 33) are clearly a result of government regulation, primarily federal regulation, since litigation against individual motorists is impracticable. The effect of this regulation-induced expenditure is evident in the substantial decline in motor vehicle emissions. Emissions per vehicle-mile 
travelled fell an astonishing 94 percent for lead between 1970 and 1985 . Hydrocarbon, carbon monoxide and nitrogen oxide emissions per vehicle mile travelled declined by 66 percent, 57 percent and 26 percent respectively. ${ }^{9}$ Substantial increases in motor vehicle use cause the total emissions to have declined much less: 46 percent and 35 percent for hydrocarbons and carbon monoxide, while nitrogen oxide emissions actually increased by 18 percent. Still, these expenditure and emissions data reveal a considerable impact of the motor vehicle emission regulation program. While economists have criticized the program for not being cost-effective, and for imposing costs that exceed benefits, there can be no doubt that the program has reduced emissions far below those that would have existed otherwise.

Expenditures for electric utility air pollution control also represent more than onethird of all air pollution control expenditures (Portney, 1990, p. 65, 66). These emissions result primarily from burning coal, and coal use multiplied by six times between 1940 and 1970 , doubling again by 1988 . Nitrogen oxide emissions, which were unregulated until very recently, grew approximately in proportion to fuel use through 1980. Particulate emissions, which have been regulated since about 1950 did not even double between 1940 and 1970, and they declined to one-third of 1940 levels by 1988 under strong regulatory pressure. Sulfur dioxide emissions grew with coal use to 1970 , but declined slowly under regulatory pressure from 1975 to 1988 (EPA 1990, p. 56). While tort played some role in electric utility emission control, as noted above, the major force behind the substantial abatement to date has been regulation, first local and state, later federal. These programs have been attacked for not being cost-effective, but while they may have been wasteful they were effective.

Another major air pollution problem was the emissions of sulfur oxides from nonferrous smelters. Early in the century, tort litigation succeeded in compelling modest reductions in emissions from some smelters, as noted above (Dewees, 1992a). The major emission reductions occurred in the 1970's and 1980's as governments imposed strict limits on smelter emissions; U.S. smelter emissions declined by 75 percent between 1970 and 1984 (Dewees 1990; GAO, 1986).

Total emissions of five of six pollutants (not nitrogen dioxide) have declined substantially between 1970 and 1980, primarily as a result of government regulation. Measured against the emissions that would have occurred if emissions had grown with economic activity the reductions range from 28 percent for nitrogen oxides, 42 percent for sulfur dioxide and hydrocarbons, 57 percent for carbon monoxide 70 percent for particulates to 97 percent for lead. Although economists continue to debate the efficiency of these regulations, there can be no doubt that regulation has achieved major reductions in emissions.

There have been significant accomplishments from regulation in certain specific areas of water pollution, notably discharges from the pulp and paper industry. Freedman and Jaggi (1986, p. 395) conclude that water pollution regulation is responsible for a $38 \%$ decline in biological oxygen demand (BOD) and a 30\% decline in total suspended solids (TSS) discharge from the pulp and paper industry from 1978 to 1983 . The effect of government inspection on regulatory success in the pulp and paper industry is noted by Magat

${ }^{9}$ Derived from EPA (1990) and data on vehicle miles travelled from the Motor Vehicle Manufacturers' Association. 
and Viscusi (1987) who conclude that the inspections under the current regulatory program caused a once and for all $20 \%$ reduction in pollutant discharges. About 1970 , emissions of mercury from chlor-alkali plants declined dramatically in a few years as the industry responded to a combination of tort litigation and regulatory initiatives (Dewees 1990). While tort was important in this abatement, government regulation was probably equally important. Freeman (1990, pp. 112-114) does not estimate reductions in discharge, but he reviews studies showing substantial, though far from complete, compliance with regulations designed to substantially reduce pollution discharge per unit of output.

The regulation of hazardous waste has taken place through the Resource Conservation and Recovery Act of 1976 (RCRA). For 1983 alone the industrial expenditures due to this regulation were estimated to be almost six billion dollars. The Congressional Budget Office has projected that the annual additional expenditure associated with the 1984 amendments to RCRA may be in the range of 3-7 billion dollars by the end of 1990 (Dower, 1990, p. 178).

In the case of hazardous waste and toxic substances, the evidence is not yet conclusive because the regulatory statutes are more recent. There is some evidence that under RCRA larger firms are beginning to shift processes and inputs toward a reduction in the amount of waste produced (Dower, 1990, p. 167).

This literature suggests that the large regulatory effort to improve the environment has met with some success when measured by pollution emissions, particularly when one recognizes the increase in emissions that might have occurred without regulation as a result of economic growth. Mills and Graves (1986, p. 251) attribute this success to other factors such as the construction of sewage treatment plants for municipal waste disposal which is "simply an improvement in the public provision of indirect discharge services", and the substitution of cleaner fossil fuels for dirtier ones, a trend that began long before the national program of discharge reductions. Yet a study of the history of smoke control (Wurts 1954) shows that an important factor in the switch to cleaner fuels in the middle of the century was regulations that banned the use of "smokey" fuels, and we have identified a number of important sectors in which regulation was a major factor if not the sole factor in inducing pollution abatement. While some important emission reductions may have resulted from factors other than pollution regulation, regulation must receive credit for a considerable proportion of the pollution control that has been achieved.

\subsubsection{Improved environmental quality}

It is more difficult to measure the effect of the environmental regulations of the 1970's on ambient environmental quality than it is to measure the effect on emission rates. Ambient concentrations depend on unregulated sources and natural sources as well as regulated sources, and are also influenced by weather that determines the dispersion of the pollution.

a. Air

There appears to have been a marked decline in ambient concentrations of the common air pollutants in the United States after the 1970 federal legislation. Between 1970 and 1980 ambient concentrations of carbon monoxide fell by $40 \%$ in urban areas, sulfur dioxide concentrations by $20 \%$, and particulate matter concentrations by $7 \%$ (Crandall and Portney 1984, p. 54). In spite of these apparent successes, ozone concentrations remained constant and concentrations of nitrogen oxide actually increased. Industrial 
activity increased by $36 \%$ and motor vehicle miles travelled increased by $37 \%$ during this period. Crandall and Portney (1984, p. 54) conclude that the regulation was successful in reducing concentrations below those that would otherwise have occurred, although it can not be shown that these improvements are attributable entirely to environmental regulation. Crandall (1983, p.21) stated that since air quality had not improved more rapidly in the 1970's than in the 1960's, it could not be said that federal regulation had achieved more than could have been achieved by continued state regulation, recognizing that regulation was the cause of the reductions, but doubting the federal role.

Later trends in the ambient concentrations of the six traditional pollutants are more encouraging. Between 1975 and 1988 average annual concentrations of lead fell by 90 percent, sulfur dioxide fell by 47 percent, and carbon monoxide fell by 46 percent. Small improvements were recorded for TSP (15 percent), nitrogen dioxide (19 percent), and ozone (12 percent). These conclusions carry some uncertainty, since the number of monitoring sites was not large for some pollutants in 1975, and because the average concentration can be biased by the selection of locations for new monitoring sites. Still, I agree with Portney (1990, p. 51) that air quality in most places in the United States has improved since 1970 .

Do the positive trends in ambient air quality attest to the success of regulation? Motor vehicles are the primary source of airborne lead, and federal regulations are clearly the reason for the massive reduction in ambient lead concentrations. Federal regulations have been directed at stationary sources of particulates and sulfur oxides, and at hydrocarbons and carbon monoxide from mobile sources, with modest regulation of nitrogen oxides from mobile sources. The major reductions in ambient concentrations have occurred with the first four substances, while there has been little improvement for nitrogen oxides. Trends in ambient concentrations are entirely consistent with the pattern of federal emission regulations.

Some have noted, however, that between 1960 and 1970, average ambient TSP levels estimated by the EPA declined by about 22 percent, and sulfur dioxide concentrations declined by 50 percent. While these figures were based on a small number of sites, they do suggest that air quality was improving before the establishment of the federal EPA and the passage of the CAA of 1970 . This does not prove however, as some analysts seem to have assumed, that there was abatement without regulation prior to 1970 ; indeed the study of smoke control concludes that very considerable improvements in local air quality arose from pre-EPA regulations. Pittsburgh was known as a smoky city for the century preceding World War II, but in 1941 Pittsburgh and a number of other major U.S. cities followed St. Louis in adopting a municipal ordinance banning the burning of smoky fuels (especially soft coal) except in equipment that would control the smoke, effective in 1946 and 1947 (Lorant 1964, p. 380). The same requirement became effective in the surrounding Allegheny County in 1950 and 1953, and in a few years the air over Pittsburgh was dramatically transformed as particulates were reduced to a fraction of their previous levels (Wurts, 1954). This attack upon particulate emissions, dubbed "smoke control", was repeated elsewhere and extended, gradually reducing heating, power plant, and industrial emissions in the decades after World War II (Thackery, 1967). Although the 1970 CAA does not appear to have caused a sharp break with the past for these two pollutants, it appears that state and local regulations reduced emissions prior to 1970 , and federal regulations caused 
further reductions thereafter, so regulatory regimes can take credit for considerable improvements in air quality over a long period of time during which population and economic activity grew considerably.

\section{b. Water}

Water quality has improved more slowly than air quality. Freeman (1990) summarizes the accomplishments of the major water pollution regulations arising from the Federal Water Pollution Control Act of 1972 (FWPCA). There has been some improvement in water quality since 1972 . Although the national average improvements is not dramatic, there are some local success stories of the cleanup of severely polluted water bodies.

One attempt to determine the efficacy of the 1972 and 1977 laws on water quality employed a model which predicted improvements in four water quality parameters as a result of FWPCA-72, holding other things constant. The study predicted that for two of the parameters FWPCA-72 led to only a modest improvement in achievement of the quality goals. Earlier regulatory efforts had achieved 83 percent and 68 percent compliance with these standards, while FWPCA-72 increased compliance by only $6 \%$ and $10 \%$ respectively. There seemed to be the greatest room for improvement for phosphorous and nitrogen since only $27 \%$ and $30 \%$ of all locations met the standards. However, it was predicted that the 1972 regulations led to only a $19 \%$ and $7 \%$ increase in the number of locations that complied with the standards. The limited effect occurs because the FWPCA dealt primarily with point sources, while non-point sources are the primary contributors to these two quality parameters (Freeman, 1990, p. 114).

A study by the Association of State and Interstate Water Pollution Control Administrators analyzed water quality for designated uses of water, such as drinking water supply, fishing, or contact recreation. Each state's water pollution control agency estimated the quality of state's streams, lakes, and estuaries for the period 1972-1982. In general, the figures show good water quality in 1982 with little improvement in all water bodies since 1972. Similar trends in water quality are reported by the National Stream Quality Accounting Network. During 1975-80, the percentage of violations of DO standards was approximately only $7 \%$, while $85 \%$ of the monitoring stations showed no change in water quality. For fecal coliform bacteria, $33 \%$ of all readings have been in violation of the standards. Again, the majority of stations reported no trend from 1974 to 1981 (Freeman, 1990, p. 118). Yet if one looks at the Great Lakes, there is clear evidence that water quality, measured by phosphorous content or the DDT content of fish, has improved significantly since the mid-1990's (Colborn et al. 1990). This improvement is attributed to limitation on the use of DDT, limits on phosphorous in detergents, and the construction of sewage treatment plants that would remove phosphorous from the discharge water. Once again, where a specific problem is identified and serous regulations adopted, emissions decline. Overall, I agree with Freeman's assessment that improvements in water quality since 1972 measured by national average data have been modest. Still, holding the line on envrionmental quality in general, and improving it in part, when economic activity has grown by over 50 percent is a substantial achievement even if it falls short of the promises for that legislation.

I have noted that we can trace the effect of regulations to discharge reduction, but the linkage between regulations and improvements in environmental quality are weak. These data are not sufficient to estimate directly the improvement in human health, reduced 
materials damage, or better ecosystem quality in most cases. I believe that such benefits have been realized, and they may be estimated indirectly using accepted dose-response functions, but the improvement in environmental quality is too small, and the ultimate benefit is not sufficiently specific to the pollution reduction to prove the relationship from aggregate data.

\section{Conclusions}

The characteristics of tort doctrines for redressing environmental harms that operated a century ago continue to exclude recovery for many environmental harms. Equally important, it is often impossible to prove that a given defendant caused the plaintiff's harm, rendering even favorable doctrines useless. The cost of the tort system precludes its use except for major harms, and with plaintiffs receiving as little as one-third of the total cost of the tort system it is a terribly inefficient means of compensating victims or deterring polluters. These input limitations are reflected in outputs - the performance of the tort system itself. Most studies of pollution abatement have attributed such successes as have occurred primarily to government regulation rather than to civil litigation. There is no evidence that civil litigation has been a major cause of the substantial control of air and water pollution that has occurred since the middle of the century, although it has been a contributing factor in some cases. The principal exception is in the field of toxic waste disposal, but here CERCLA has created new civil actions, and extensive regulations compel careful handling of toxics. A leading environmental law casebook devotes less than 10 percent of its pages to civil litigation (Grad 1985). These considerations suggest that tort is most effective for local pollution problems involving a single polluter and very substantial damage, and is of little significance for pollutants dispersed in low concentrations over a large area, or discharged in a developed area with many other pollution sources, including most air and water pollution problems. Indeed it appears that much of the expansion of environmental tort litigation in the last decade has involved property damage, where it was relatively easy to prove that the presence of the toxic waste had reduced property values or required costly remedial measures.

In contrast, it is clear that government regulation has substantially reduced some pollution emissions. Automotive emissions have been greatly reduced in total since 1970, despite considerable growth in motor vehicle usage. Emissions of particulates have fallen dramatically during the last half century in part because of the abandonment of coal for railroads and for home heating, but at least equally because of local, state and federal regulation of particulate emissions. Emissions of sulfur dioxide have declined somewhat, again because of the regulation of major sources such as smelters and power plants. Improvements in water pollution discharge have been important but more modest, in part because major classes of sources, such as non-point sources, have barely been regulated. Improvements in toxic waste disposal have arisen from a combination of regulation and fear of civil liability under CERCLA, or of common law tort liability.

To some extent regulation has succeeded where tort has failed, as in the case of motor vehicle emission regulation and the control of particulate and sulfur oxide emissions from stationary sources. In other cases both have failed for similar reasons. If there is limited evidence that a pollutant causes harm, it is difficult to justify regulating its emission. If thousands of small sources discharge a pollutant the cost of monitoring that discharge may be large relative to the benefits of controlling it, whether the control is motivated by civil 
litigation or by government regulation. And with thousands of pollutants to be regulated, the process of setting technology-based emission standards is enormously time-consuming and costly, so that years or decades will be required to promulgate regulations covering the list of substances that we currently worry about.

Despite the serious limitations of tort law and the clear imperfections of the regulatory system, I am not persuaded that a general expansion of the tort system is warranted. Many of the barriers to suit arise from genuine uncertainty about cause and effect relationship which cannot be resolved by changes in the law. Tort litigation is enormously costly, highly uncertain in its outcome, and may deal with only one source at a time. The wise course may be to continue to allow tort to do what it does best - resolve disputes between a victim and his injurer when the individual harm is great and the causal relationship can be clearly established, and leave to the regulatory authorities the control of pollutants of questionable harm to large numbers of persons and to the general environment. There may also be a useful role for statutory civil liability to supplement or replace tort for environmental problems in which the harm is largely private and can be valued easily, although the CERCLA experience reveals that legislation may create new problems as well as solving existing ones. The deterrent effect of tort and of legislation may be augmented by expanding the authority of private citizens to enforce environmental laws and regulations, particularly substantive regulations, as a means of allowing private individuals to ferret out violations of the law and cause enforcement to be more responsive to local concerns than is possible with a government monopoly on prosecution. Before embracing such "private enforcement", however, one should ensure that the substantive regulations set appropriate limits and do not rely upon prosecutorial discretion to achieve reasonable results. 


\section{REFERENCES}

ABEL, Richard (1987), "The Real Tort Crisis - Too Few Claims", Ohio State L.J. 68, p. 443.

ABRAHAM, Kenneth (1988), "Environmental Liability and the Limits of Insurance", Columbia Law Review 88, p. 942.

ASHWORTH, J., PAPPS, I. and STOREY, D. (1987), "Assessing the Impact upon the British ChlorAlkali Industry of the EEC Directive on Discharges of Mercury into Waterways", Land Economics 63: $72-78$.

BAUMOL, William J. and OATES, Wallace E. (1988), The Theory of Environmental Policy, New York: Cambridge University Press.

BRATTON, David and RUTLEDGE, Gary (1990), "Pollution Abatement and Control Expenditures, 1985-88", U.S. Department of Commerce, Survey of Current Business, 70: 11, p. 32, November.

BRENNAN, Douglas F. (1986), "Joint and Several Liability for Generators Under Superfund: A Federal Formula for Cost Recovery", U.C.L.A. Journal of Environmental Law 5, p. 101.

BRENNAN, Troyen (1988), "Causal Chains and Statistical Links: The Role of Scientific Uncertainty in Hazardous-Substance Litigation", Cornell L. Rev. 73, p. 469.

BRENNAN, Troyen (1991), "Environmental Injuries", Chapter 11 in American Law Institute, Enterprise Responsibility for Personal Injury, Volume I, The Institutional Framework, Report to the ALI, Philadelphia.

BRENNER, Joel F. (1974), "Nuisance Law and the Industrial Revolution", Journal of Legal Studies 3 , p. 403.

BRODEUR, Paul (1985), Outrageous Misconduct: The Asbestos Industry on Trial, New York: Pantheon.

COASE, Ronald N. (1960), "The Problem of Social Cost", J. Law and Econ. 3, p. 1.

COLBORN, Theodora E., DAVIDSON, Alex, GREEN, Sharon N., HODGE, R. A., JACKSON, C. Ian, LIROFF, Richard A. (1990), Great Lakes Great Legacy? Baltimore: The Conservation Foundation.

COOTER, Robert and ULEN, Thomas (1988), Law and Economics, Glenview, III.: Scott, Foreman.

CRANDALL, R. W. (1983), Controlling Industrial Pollution, Washington: The Brookings Institution.

CRANDAll, R. and PORTNEY, P. R. (1984), "Environmental Policy" in P. R. Portney (ed.) Natural Resources and the Environment: The Reagan Approach, pp. 47-81, Washington: The Urban Institute.

"Developments in the Law: Toxic Waste Litigation", (1986), Harvard Law Review 99, 1458.

DEWEES, Donald N. (1986), "Economic Incentives for Controlling Industrial Disease: The Asbestos Case", Journal of Legal Studies 15, p. 289.

DEWEES, Donald N. (1990), "The Effect of Environmental Regulation: Two Case Studies" in M. Friedland (ed.), Securing Compliance: Seven Case Studies, Toronto: University of Toronto Press.

DEWEES, Donald N. (1992a), "The Efficiency of the Common Law: Sulphur Dioxide Emissions in Sudbury". University of Toronto Law Journal 42, p. 1.

DEWEES, Donald N. (1992b), "Tort Law and the Deterrence of Pollution", in Tietenberg, Thomas ed., Innovation in Environmental Policy, Aldershot, UK: Edward Elgar.

DEWEES, Donald N., and DANIELS, R. (1988), "Prevention and Compensation of Industrial Disease", International Review of Law and Economics, 8: 51-72.

DEWEES, Donald N. and TREBILCOCK, M. J. (1991), "The Efficacy of the Tort System and Its Alternatives: A Review of the Empirical Evidence", University of Toronto, Law and Economics Working Paper Series \# 1 . 
DOWER, R.C. (1990), "Hazardous Wastes", in P. R. Portney (ed.), Public Policies for Envrionmental Protection, pp. 151-193, Washington: Resources for the Future.

Environmental Law Institute (1980), Six Case Studies of Compensation For Toxic Substances Pollution: Alabama, California, Michigan, Missouri, New Jersey, and Texas, Washington, D. C.: Congressional Research Service, Library of Congress.

Environmental Protection Agency (EPA) (1990), U.S. Environmental Protection Agency, National Air Pollutant Emission Estimates 1940 - 1988, Washington D.C.: USEPA, Doc. No. EPA-450/4-90-001.

Environmental Protection Agency (EPA) (1989), National Air Quality and Emissions Trends Report, 1987, Washington: USEPA, Doc. No. EPA-450/4-89-01.

FREEMAN, A.M. (1990), "Water Pollution Policy", in P. R. Portney (ed.) Public Policies for Environmental Protection, pp. 97-149, Washington: Resources for the Future.

FREEDMAN, M.J. and JAGGI, B. (1986), "Impact of Government Regulations on Pollution Performance of Pulp and Paper Firms", Environmental Management 18, pp. 391-396.

General Accounting Office (GAO), (1986), Air Pollution: Sulphur Dioxide Emissions from NonFerrous Smelters Have Been Reduced, Report to the Subcommittee on Oversight and Investigations, Committee on Energy and Commerce, House of Representatives.

GRAD, Frank P. (1985), Environmental Law, 3rd. ed., New York: Matthew Bender.

GRINDER, R. D. (1980), "The Battle for Clean Air: The Smoke Problem in Post-Civil War America" in Martin V. Melosi, ed. Pollution and Reform in American Cities, 1870-1930, Austin: U. of Texas Press.

HENSLER, Deborah (1987), "Trends in Tort Litigation: Findings from the Institute for Civil Justice's Research”, Ohio State L.J., 48, p. 479.

HUBER, Peter (1988), "Environmental Hazards and Liability Law" in Robert Litan, Clifford Winston (eds.) Liability: Perspectives and Policy, Washington: Brookings Institute, p. 128.

KAKALIK, James S., EBENER, Patricia A., FELSTINER, William L.F. and SHANLEY, Michael G. (1983), The Costs of Asbestos Litigation, Santa Monica: Institute for Civil Justice.

KAKALIK, J. and PACE, N. (1986), Costs and Compensation Paid in Tort Litigation, Santa Monica: Institute For Civil Justice.

KEETON, W.P., DOBBS, D. B., KEETON, R. E. and OWEN, D. G. (1984), Prosser and Keeton on Torts, (5th edn.), St. Paul: West Publishing Co.

LANDES, William M. and POSNER, Richard A. (1987), The Economic Structure of Tort Law, Cambridge: Harvard University Press.

LINDEN, A.M. (1988), Canadian Tort Law (4th edition), Toronto; Butterworths.

LORANT, Stefan (1964), Pittsburgh, Garden City: Doubleday.

MAGAT, W. and VISCUSI, W. K. (1990), "Effectiveness of EPA's Regulatory Enforcement : The Case of Industrial Effluent Standards", Journal of Law and Economics 33, October.

MENDELOFF, J.M. (1988), The Dilemma of Toxic Substance Regulation, Boston: MIT Press.

MILlS, E.S. and GRAVES, P.E. (1986), The Economics of Environmental Quality, New York: Norton.

POLINSKY, A. Mitchell (1989), An Introduction to Law and Economics (2nd ed.), Boston: Little, Brown.

PORTNEY, P. R. (1990), "Air Pollution Policy", in P. R. Portney (ed), Public Policies for Environmental Protection, pp. 27-96, Washington: Resources for the Future. 
POSNER, Richard A. (1986), Economic Analysis of Law, 3rd. ed., Boston: Little Brown.

REUTER, Peter (1988), "The Economic Consequences of Expanded Corporate Liability: An Exploratory Study", Santa Monica: The Rand Corporation, N-2807-ICJ.

RUTLEDGE, Gary and STERGIOULAS, Nikolaos (1988), "Plant and Equipment Expenditures by Business for Pollution Abatement, 1987 and Planned 1988", U.S. Department of Commerce, Survey of Current Business, 68:11, p. 26 (November).

RUSSELL, C.S. (1990), "Monitoring and Enforcement", in P. R. Portney (ed.) Public Policies for Environmental Protection, pp. 243-274, Washington: Resources for the Future.

SCHUCK, Peter (1986), Agent Orange on Trial: Mass Toxic Disaster in the Courts, Cambridge: Belknap Press.

SHAPIRO, M. (1990), "Toxic Substances Policy", in P. R. Portney (ed.) Public Policies for Environmental Protection, pp. 195-241, Washington: Resources for the Future.

SHAVELl, Steven (1987), Economic Analysis of Accident Law, Cambridge: Harvard University Press.

SUGARMAN, Stephen (1987), "Doing Away with Tort Law", Calif. L. Rev. 73, p. 558.

THACKERY, T.O. (1967), "Pittsburgh : How One City Did It", in Controlling Pollution, New Jersey; Prentice-Hall.

TIETENBERG, T. (1988), Environmental and Natural Resource Economics, 2nd. edn., Glenview: Scott, Foresman and Company.

WEINRIB, Ernest (1989), "Understanding Tort Law”, Valparaiso L. Rev. 23, p. 485.

WURTS, Thomas C. (1954), "Sensible Smoke Control", paper presented to the American Gas Association Conference, Pittsburgh, May, 1954. 